Abstracta Iranica Abstracta Iranica

Revue bibliographique pour le domaine irano-aryen

Volume 28 | 2007

Comptes rendus des publications de 2005

\title{
Afghanistan. Ancien carrefour entre l'est et l'ouest. Turnhout, Brepols, 2005, 539 p.
}

Étienne de La Vaissière

\section{Q OpenEdition}

1 Journals

Édition électronique

URL : http://journals.openedition.org/abstractairanica/14672

DOI : 10.4000/abstractairanica. 14672

ISSN : 1961-960X

\section{Éditeur :}

CNRS (UMR 7528 Mondes iraniens et indiens), Éditions de l'IFRI

\section{Édition imprimée}

Date de publication : 15 mai 2007

ISSN : 0240-8910

\section{Référence électronique}

Étienne de La Vaissière, «Afghanistan. Ancien carrefour entre l'est et l'ouest. Turnhout, Brepols, 2005, 539 p. », Abstracta Iranica [En ligne], Volume 28 | 2007, document 53, mis en ligne le 18 septembre 2007, consulté le 25 septembre 2020. URL : http://journals.openedition.org/abstractairanica/14672 ; DOI : https://doi.org/10.4000/abstractairanica.14672

Ce document a été généré automatiquement le 25 septembre 2020.

Tous droits réservés 


\title{
Afghanistan. Ancien carrefour entre l'est et l'ouest. Turnhout, Brepols, 2005, 539 p.
}

\author{
Étienne de La Vaissière
}

Ces actes de la conférence de Lattes (mai 2003) comprennent plusieurs articles importants parmi lesquels je relèverais : F. Thierry, "Yuezhi et Kouchnas. Pièges et dangers des sources chinoises» (pp.421-539) un véritable cours de méthode sur l'utilisation des données chinoises pour l'écriture de l'histoire centre-asiatique, ici centré sur les textes traitant des Yuezhi et de leurs liens avec les Kouchans, mais qui s'applique également à d'autres époques. Il faut mentionner également l'article de R. Salomon, "The Indo-Greek era of 186/185 BC on a Buddhist reliquary inscription » (pp. 359-402) où est éditée une inscription donnant la concordance chronologique entre l'ère d'Azès et "l'ère des Grecs ». G. Fussman lors de la discussion a mis en doute l'authenticité de l'inscription. C'est également un problème direct d'authenticité qui se pose à propos d'une tête d'un Boddhisattva barbu présentée par M. Carter. L'ouvrage comprend également des études de numismatique, d'iconographie ou de géographie historique, de l'âge du bronze au VII ${ }^{\mathrm{e}}$ s. de n.è.

\section{INDEX}

Thèmes : 3.1. Est de l'Iran 
AUTEURS

ÉTIENNE DE LA VAISSIÈRE

ENS - EPHE - Paris 